\title{
公共交通機関を考慮した歩行者の都市内アクセシビリティの定量的評価手法 A METHOD FOR QUANTITATIVE EVALUATION OF URBAN PEDESTRIANS
ACCESSIBILITY BY PUBLIC TRANSPORT
}

レフォン グェン*，吉川徹**

LE Phong Nguyen and Tohru YOSHIKAWA

\begin{abstract}
This research focuses on walkability and accessibility, aims to evaluate travel quality of each public transport in urban areas by using algorithmic models to analyze travelling time as well as physical and mental consumption index of public transport users. In addition, the study also conducts quantitative analysis on travelling quality in order to evaluate accessibility and applies the developed model to the central area of Utsunomiya City in order to verify the model. The study gives specific results in convenience level of each public transport means which can be used as a basis for establishing the assessments and selection of most suitable transports in urban planning.
\end{abstract}

Keywords : Population ageing, convenience, commuting time, moving cost, Bus rapid transit (BRT), distance between stations 高齢化, 利便性, 移動時間, 移動コスト, BRT, 駅間距離

\section{1. はじめに}

\section{1 研究の背景と目的}

近年、住環境の基本理念の一つである利便性を向上させる政策 を国内外の都市が採用している。そのなかでもBRT（Bus Rapid Transit）などの新しい公共交通システムの導入によって、都市内の 平均移動時間を短縮し、生活環境を確保しながら交通の利便性を改 善する例が多い ${ }^{1)}$ 。特に、超高齢社会になった日本においては、人口 年齢構成や密度などの変化に対応した公共交通の見直しは必要であ る。したがって、公共交通の維持・拡充策として、速達性・定時性 の確保のみならず都市の規模・形態と需要密度に適合性が高い交通 機関の選択は重要である。

都市内移動時間は都市構成の指標の一つである。移動時間短縮に は、各交通機関の速度や駅密度の他、各地点と駅の乗降口の間の徒 歩も大きな影響を及ぼす。さらに、目的地点までの移動距離により、 各交通機関の得失も異なる。また、年齢階級ごとの都市内移動に伴 う体力的な負担にも大きな相違がある。このことから、公共交通機 関を計画する際に、居住者および利用者の年齢階級による身体能力 の状態に応じて、利用可能距離を低減させることは、利便性の高い 都市環境の実現の上で重要である ${ }^{2)}$ 。特に、コンパクトシティ形成が 重要な施策として注目され、歩行者の立場から徒歩と近距離の公共 交通機関を適切に融合させた都市計画が求められている中で、その 重要性は高まっている。
本研究では上記の問題意識に立って、利便性の重要な評価要因で ある、都市内での移動時間および公共交通機関を利用する際の移動 負担から見た各公共交通機関の得失を明らかにする。さらに、各交 通機関の得失によって移動負担を定量化することにより、都市内ア クセシビリティを評価する手法を開発し、これを実際の地方都市に 適用して検証することを目的する。

\section{2 研究の位置づけ}

徒歩からみた都市内アクセシビリティに関する先行研究を踏まえ、 本研究の特徴について述べる。

徒歩距離に関する研究について山塙・吉田・佐土原 ${ }^{3)}$ は、徒歩と バスと電車でアクセス寸ると考えて最寄り駅および生活関連施設ま でのアクセシビリティを評価した。高齢化率が高い、利便性が低い 地域では、駅の方向へ誘導するなどの、地域の特徴にあった対策を 行っていかなければならないと示唆している。繁野・吉川・讃岐 ${ }^{4)}$ は、 「距離、横断、右左折の 3 つの徒歩移動抵抗と施設立地には大きな相 関があり、抵抗の大きさが無目的施設と有目的施設の分布に影響を 与えていること」を示した。池田・出口 ${ }^{5)}$ は距離種類として、誘致 距離と施設間距離を用いて、高齢者の歩行距離から市街地のコンパ クト性を評価する手法を作成した。

年齢階級ごとの歩行のエネルギー消費に関する研究の例としては、 歩行運動によるエネルギー消費の側面から効率的な歩行について比 較するために、歩行速度や勾配が呼吸・循環機能にどのような影響
* 首都大学東京大学院都市環境科学研究科建築学域 博士後期課程

** 首都大学東京大学院都市環境科学研究科建築学域 教授・博士 (工学)
Doctoral Course in Architecture and Building Engineering, Tokyo Metropolitan University, M.Eng

Prof., Dept. of Architecture and Building Engineering, Tokyo Metropolitan University, Dr.Eng. 
を及ぼすのか実験した杉山ら ${ }^{6)} や 、$ 平地の歩行速度の推定法を検討 し、歩行や階段昇降などの運動時による消費カロリーを推定した煤 孫ら ${ }^{7)}$ が挙げられる。

移動コストの定量化に関しては、大佛・津田 ${ }^{8)}$ が都市内移動をモ デル化し、各移動手段の移動距離、移動手段切り替え回数、坂道抵 抗を用いて移動コストを定式化した。一方、佐藤ら ${ }^{9)}$ は駅内移動の 対象として「都市公共交通ターミナルにおける乗換抵抗を時間のみ ではなく肉体的負担、心理的負担など様々な負担を考慮した乗換行 動に起因する単位時間あたりの抵抗を貨幣換算したものを乗換行動 コスト」と称した。

以上のように、都市内アクセシビリティの評価要因として徒歩距 離・歩行のエネルギー消費・移動コストに関する研究が様々な対象 に検討されているが、研究の背景で重要性を指摘した、徒歩と近距 離の公共交通機関を適切に融合させる観点から評価した総合的研究 は少ない。そこで本研究では、上記の既往研究の成果を踏まえ、歩 行者の立場から各公共交通機関による都市内移動に着目し、都市内 アクセシビリティを定量化する。特に高齢社会における公共交通機 関利用時の徒歩移動抵抗に着目し、市民の都市内移動にどのように 影響を与えるのかを検討する。これにより、公共交通機関の都市内 への導入がもたらす建築・都市空間におけるアクセシビリティ改善 効果を定量化し、それらの比較を行い、適切な公共交通機関の選出 とそれによる都市内アクセシビリティ変化の特徴抽出について分析、 考察を行う点が、本研究の特徵である。

\section{3 対象地域}

本研究では宇都宮市の中心部に位置する宇都宮駅周辺の地域を実 証研究の対象とする。交通渋滞や都市環境悪化等の問題を解決する ために、栃木県と宇都宮市は、平成 $13 \sim 14$ 年度の 2 力年で「新交 通システム導入基本計画策定調查」を実施した ${ }^{10)}$ 。様々な新交通シ ステムの検討がなされた結果、LRT (Light Rail Transit) が採用さ れた。LRTの計画路線約 $15 \mathrm{~km}$ 付近には、公共交通の拠点となる東武 宇都宮駅や JR 宇都宮駅があるほか、公共公益施設、大型ショッピン グセンターや工業団地などとの連携が計画されている。そこで本研 究では、計画路線の一部 (約 $7 \mathrm{~km}$ ) の周辺地域を対象とし、現状人 口条件 (約 15 万人) で各公共交通機関による都市内アクセシビリティ の評価を行う。

2. 公共交通機関を考慮した都市内アクセシビリティの定量的評価手 法の定式化

本章では、都市内アク セシビリティを定量的に 評価する手法を定式化し て、その基本的性質を確 認するために仮想都市に

\section{表 1 公共交通機関の仮定条件}

\begin{tabular}{c|c|c}
\hline 交通機関 & 速度 $(\mathrm{m} /$ 分) & 駅間距離 $(\mathrm{m})$ \\
\hline \hline バス & 334 & 300 \\
\hline BRT & 501 & 600 \\
\hline 地下鉄 & 667 & 1200 \\
\hline \multicolumn{2}{|c}{}
\end{tabular}

表 2 年齢段級ごとのエネルギー消費量の係数

\begin{tabular}{c|c|c|c|c}
\hline $\begin{array}{c}\text { 年齢 } \\
(\text { 歳 }\end{array}$ & $\begin{array}{c}\text { 徒歩速度 } \\
(\mathrm{m} / \text { 分 })\end{array}$ & RMR 值 & $\begin{array}{c}\text { BMR } \\
(\mathrm{kcal} / \mathrm{kg} / \text { 日 })\end{array}$ & $\begin{array}{c}\text { 体重 } \\
(\mathrm{kg})\end{array}$ \\
\hline \hline $10-14$ & 66.5 & 2.2 & 34.2 & 42.3 \\
\hline $15-29$ & 88 & 3.8 & 25.5 & 61.5 \\
\hline $30-49$ & 86.1 & 3.6 & 22.3 & 68.5 \\
\hline $50-69$ & 70.7 & 2.5 & 21.5 & 65.3 \\
\hline $70-$ & 57.4 & 1.8 & 21.5 & 60 \\
\hline
\end{tabular}

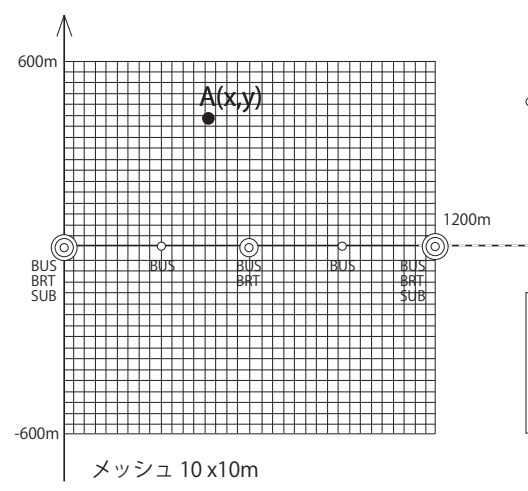

○バス ○BRT ○地下鉄

図 1 都市内移動モデル

適用する。この手法においては、下記のように、都市内移動モデル に基づいて移動時間と身体的なエネルギー消費量を算出することで、 都市内アクセシビリティの評価を行う。

\section{1 都市内移動モデルと線形都市の概要}

対象とする公共交通機関は代表的な都市内公共交通機関である、

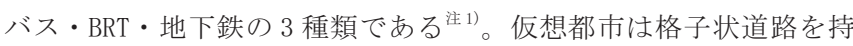
ち、 $1200 \times 1200 \mathrm{~m}$ の範囲の任意地点から、その外にある目的地点ま での徒歩および公共交通機関の利用による移動時間と身体的なエネ ルギー消費量の解析を行う。目的地点までの移動距離は、地方都市 の都市内移動を想定して、1200m，4800m，9600m とする。

既往研究 ${ }^{1,11,12)}$ により、各公共交通機関の条件を表 1 のように仮 定する。また、徒歩に関する評価を行うため、日本人の年齢別の平 均徒歩速度 ${ }^{13)}$ 、エネルギー代謝率 (RMR) ${ }^{14)}$ 、基䃈代謝率 (BMR)、体重 (W) ${ }^{15}$ を表 2 のように設定した。仮想都市は図 1 に示した通りであり、 図中に $\mathrm{A}(\mathrm{x}, \mathrm{y})$ で示した任意地点である $\mathrm{A}$ 点から 1200，4800，9600m 距離にある目的駅までの移動時間を計算する。移動時間 T は下記の $\mathrm{T}_{1}, \mathrm{~T}_{2}$ の合計時間とする。 $\mathrm{T}_{1}$ は $\mathrm{A}$ 点から $\mathrm{S}_{2}$ 駅までの最短移動時間とす る。これは、図 1 の枠内に示すように、 $A$ 点から $S_{1}$ 駅まで徒歩、 $S_{1}$ 駅から $\mathrm{S}_{2}$ 駅まで公共交通機関で移動するか、 $\mathrm{A}$ 点から $\mathrm{S}_{2}$ 駅まで直接 徒歩移動するか、どちらか最短移動時間になる方を選択して求める。 $\mathrm{T}_{2}$ は交通機関の利用による $\mathrm{S}_{2}$ 駅から目的駅までの移動時間とする。 本章の仮想都市においては、基本的性質を確認するために、単純な 線形都市を想定して公共交通機関の待ち時間や階段の上り下りなど は考慮しない。

\section{2 移動のエネルギー消費量の定式化}

移動時間結果に基づいてバス停や駅などまでの徒歩時と交通機関 利用時の 2 つに段階を分け全体移動時のエネルギー消費量 $\mathrm{E}=\mathrm{E}_{\mathrm{w}}+\mathrm{E}_{\mathrm{p}}$ を算出する。徒歩時間 $\mathrm{T}_{\mathrm{w}}$ のエネルギー消費量 (Kcal) は以下の式 1 により求める ${ }^{7,14,16)}$ 。

$\mathrm{E}_{\mathrm{w}}=(\mathrm{RMR}+1.2) \times B M R \times \mathrm{W} \times \mathrm{T}_{\mathrm{w}}$

徒歩時の酸素消費量はその速度と関係があるため、同一の徒歩行 動においても酸素摂取量に個人差がある。本研究においては、年齢 階級ごとの基礎代謝量（BMR）および椂々な身体活動時の基礎代謝に 対する比率であるエネルギー代謝率 (RMR) は、佐藤らより人間工学 の分野で算出されている代表的なものを使用した（表 2) ${ }^{16}$ )。また、 公共交通機関の利用時間 $\mathrm{T}_{\mathrm{p}}$ のエネルギー消費量（KCAL）は式 2 によ り求める ${ }^{17,18)}$ 。

$\mathrm{E}_{\mathrm{p}}=1.05 \times$ METS $\times W \times \mathrm{T}_{\mathrm{p}} \quad$ (安静時 $\mathrm{METS}=1$ とする) 


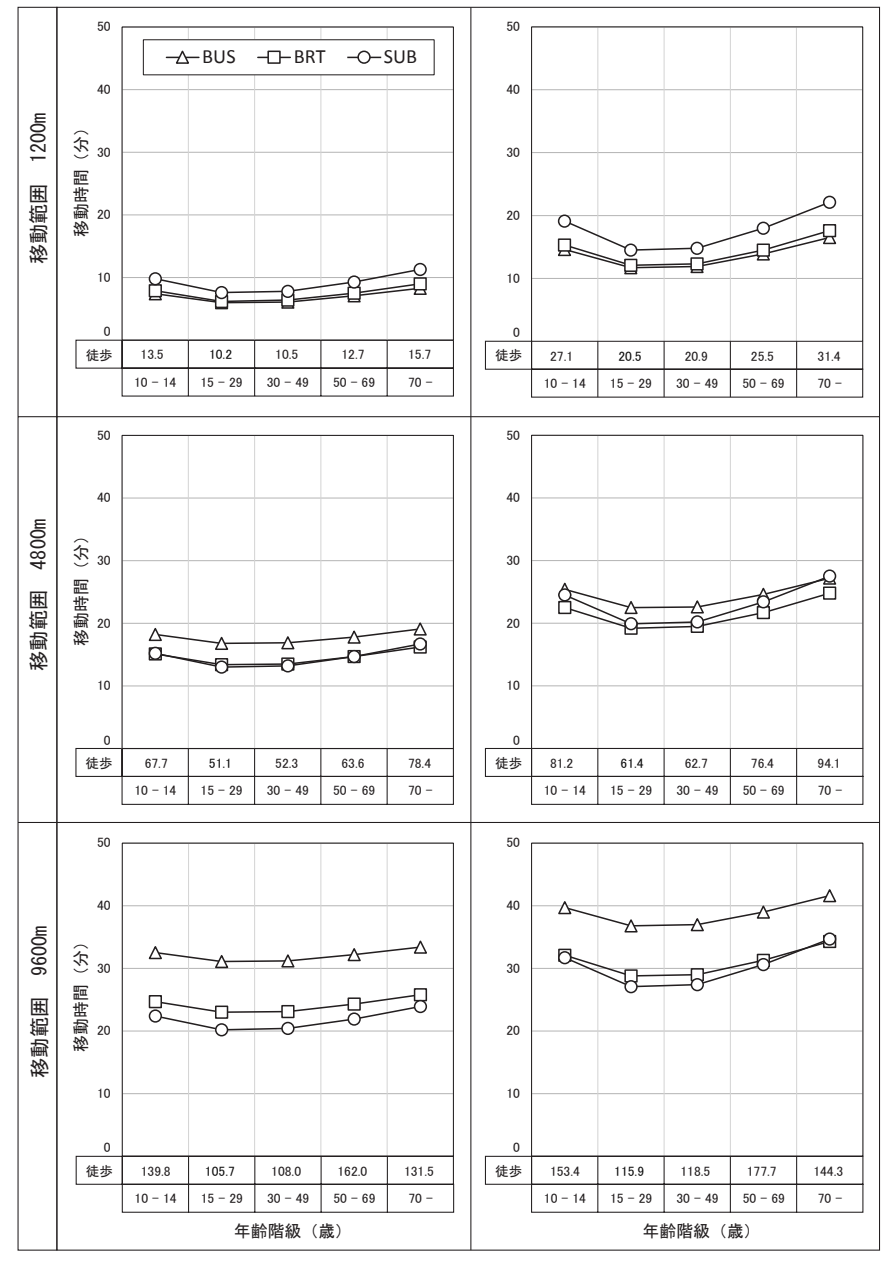

図 2 年齢階級ごとの移動時間

METS（メッツ）とは「運動や身体活動の強度の単位で、安静時（座つ ている状態）を 1 とした時と比較して何倍のエネルギーを消費する かで活動の強度を示寸」19) ものである。本研究では、各公共交通機 関の利用時は安静状態と想定寸れば、消費カロリーは利用時間およ び体重の比率により求めることができる。

\section{3 仮想都市における移動時間による評価}

任意地点から目的地点までの徒歩および交通機関の利用による移 動時間の平均值および最大值を図 2 に示す。比較のため、徒歩のみ による值をグラフの下に付記した。徒歩のみによる值に比べて交通 機関利用の值は小さく、また移動距離によって各交通機関の得失は 相対的に逆転する。

図 2 中の平均時間結果により、短距離移動範囲 (1200m) の場合は BRT と地下鉄よりバスの方が移動にかかる時間が短いことが分かる。 理由はバス停の間隔 $(200 〜 300 \mathrm{~m})$ が非常に短いことにより、短時 間でバス停まで徒歩移動が可能で、公共交通機関がすぐ利用出来る からだと考えられる。一方、BRT または地下鉄を利用する際には、 出発地点の位置が全体の移動時間に大きな影響を及ぼす。駅間距離 (600m, 1200m) が長いため、駅までの徒歩移動時間が長く交通機関 が利用できるまでの時間が非常にかかる地点がある。このため、短 距離移動の場合はバス利用の方が有利である。また、最大值の結果 からみると、バス停や駅などの交通機関停留場から離れた場所は地 下鉄は他の交通機関よりアクセシビリティが低い。

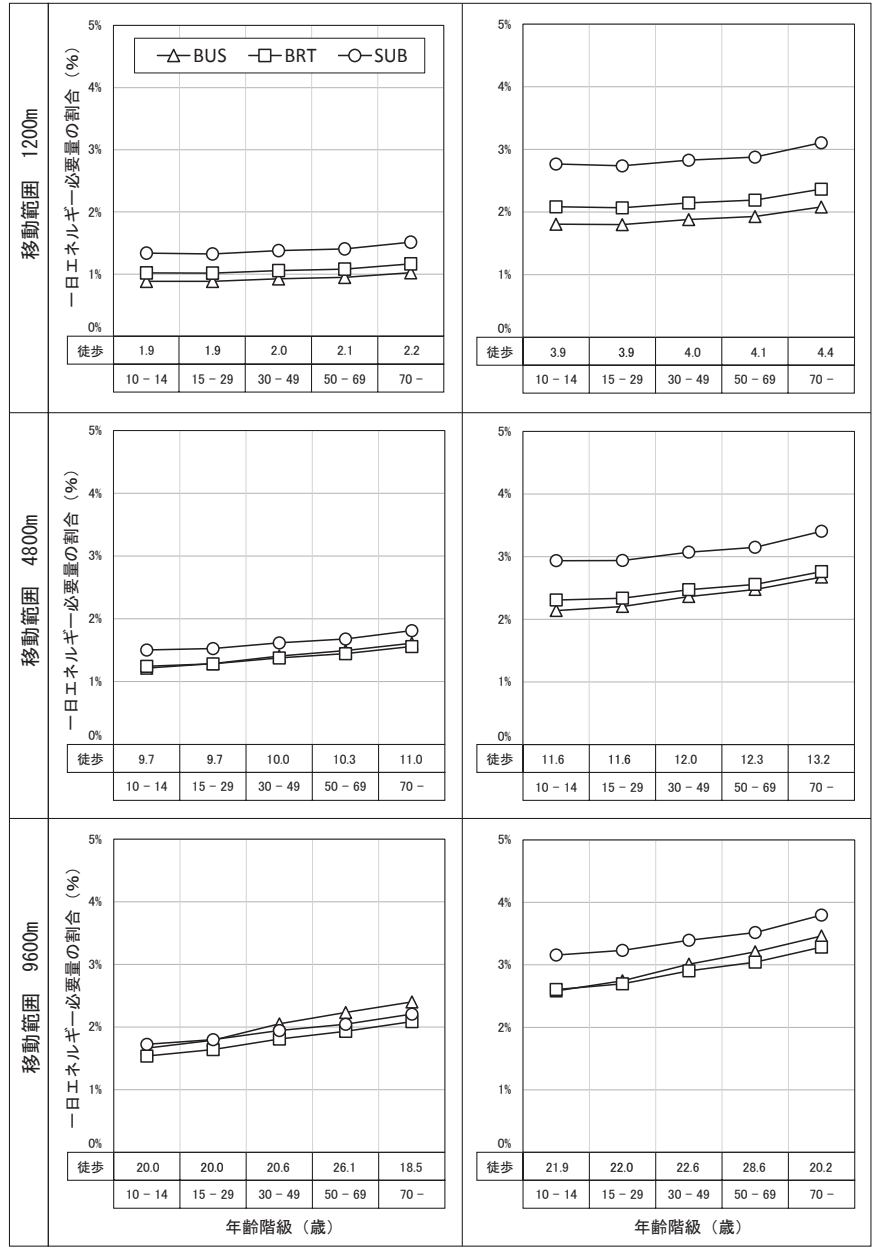

図 3 年齢階級ごとの移動による一日エネルギー必要量に対する割合

移動距離範囲が 4800m である場合は BRT と地下鉄よりバスの方が 平均の移動時間が長い場合が多い。BRT と地下鉄は、駅までの徒歩 距離が他の交通機関に比べて長いが、乗車してからは移動距離が長 いほどメリットが出てくる。速達性に優れるため、長距離で利用寸 るとバスより移動時間が非常に短くなることが分かる。このことは、 $9600 \mathrm{~m}$ の距離範囲で移動する場合にはさらに顕著であり、バスより BRT と地下鉄を利用した方が早い。特に BRT は地下鉄より駅間の間 隔が半分程度と短いことが、長距離移動であっても高い利便性を与 えることが分かる。同様に最大值の結果から、最も利便性が低い地 点においても移動距離範囲によって公共交通機関の得失も逆転する ことが分かる。これらの結果から、都市内移動の駅までの徒歩時間 が公共交通機関に大きな影響を与えると言える。

各年齢の移動時間については、徒歩速度の相違のため移動時間が 年齢階級ごとに大きく変化している。高齢者（70 歳以上）の移動時 間が他の年齢より圧倒的に大きい。徒歩速度が遅いことが、駅まで の徒歩時間が全体の移動時間に大きい影響を与える。さらに、それ ぞれの移動範囲ごとの平均值と最大值を比較すると、最大值の方が 年齢ごとの差が大きい傾向がある。これらのことより、高齢者は、 公共交通機関利用時の移動時間に、他の年齢より徒歩時間が大きく 影響を及ぼすことが分かり、超高齢社会となった日本では深刻な問 題となることが懸念される。

\section{4 エネルギー消費量による評価}



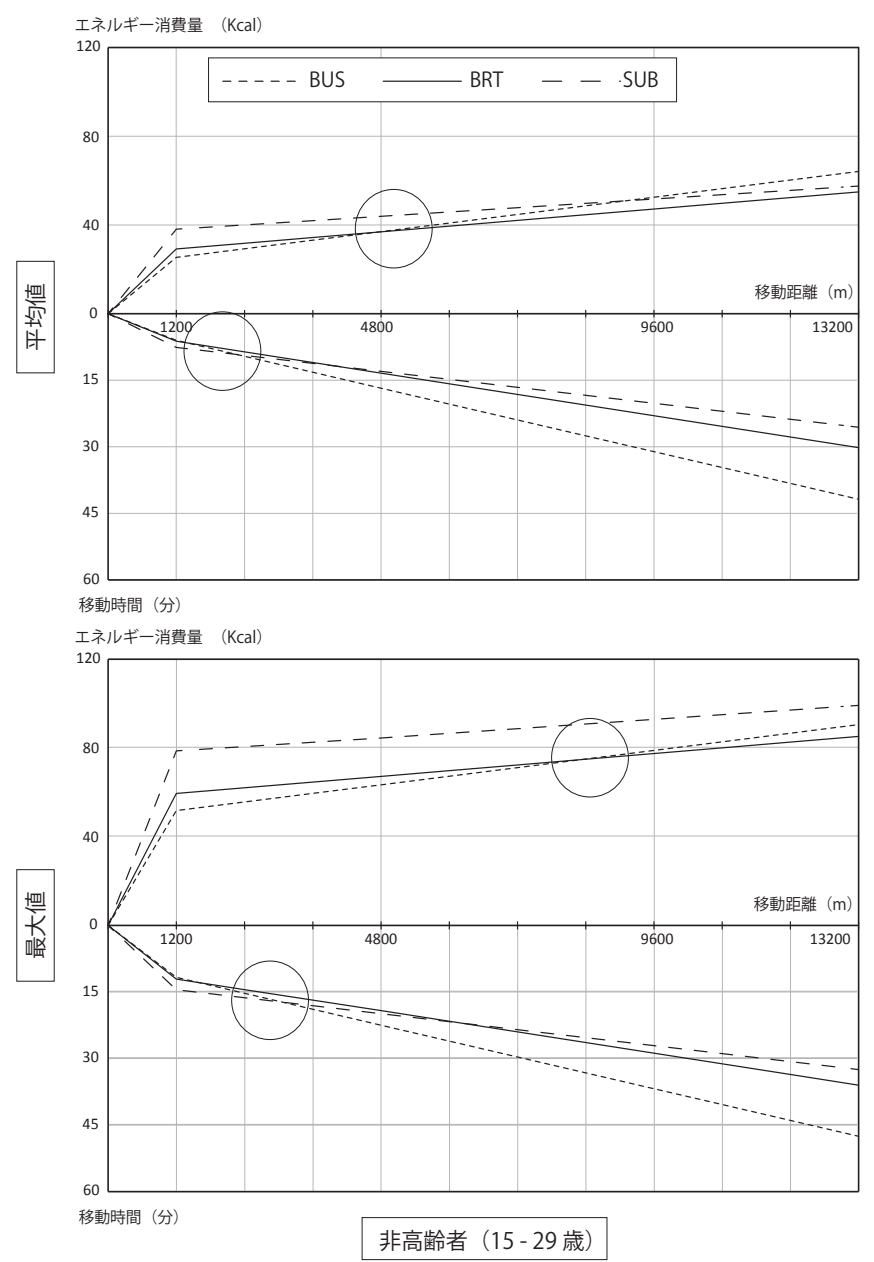

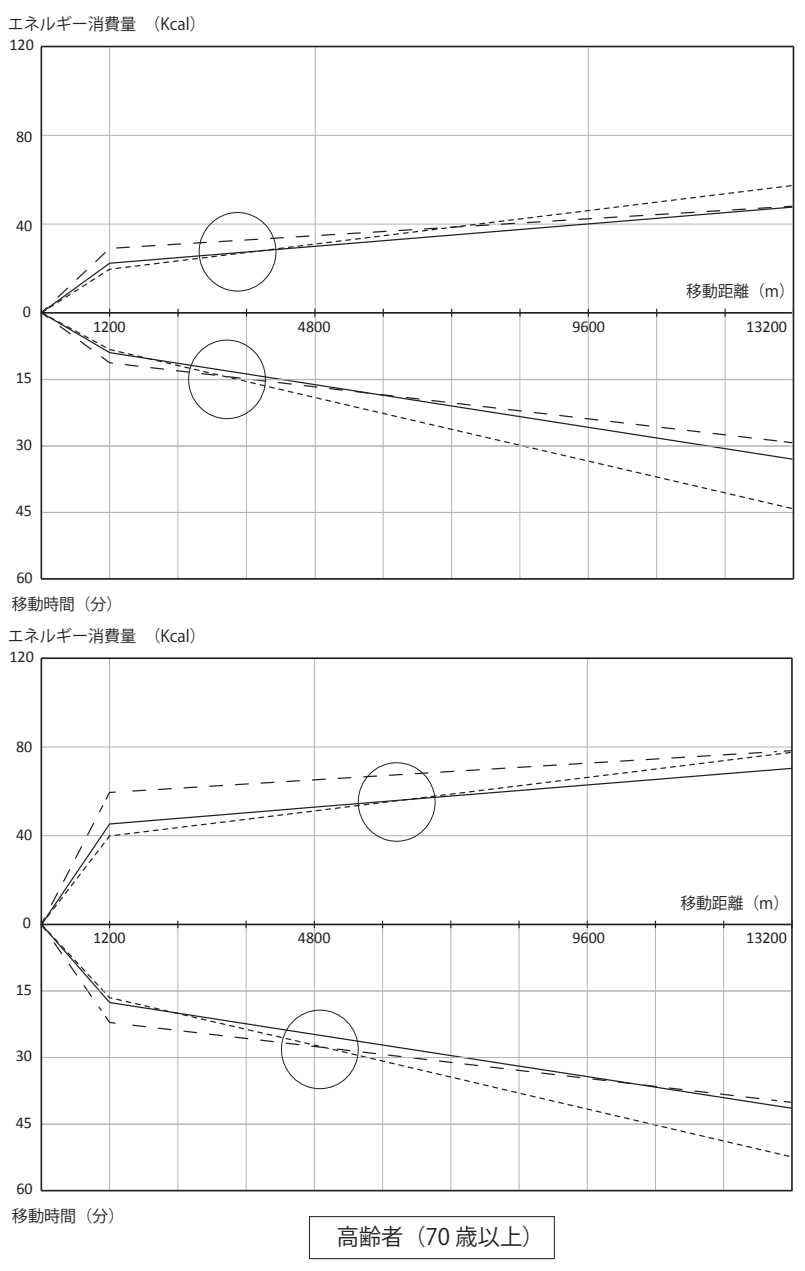

図 4 移動距離による各公共交通機関のメリット
既報 ${ }^{20)}$ により、一般的に加齢に伴って筋肉などの除脂肪量の低下 により、活動時のエネルギー代謝量が低くなることがある。したが って、総エネルギー消費量も加齢に伴い低下していく。本研究の手 法においても、バス停や駅までの徒歩によるエネルギー消費量 (式 1）はエネルギー代謝率（RMR）と比率するため、徒歩速度が早ければ 早いほどエネルギー消費量が大きいことが示せる。これにより、高 齢者の徒歩速度が下がるため、他の年齢に比べて徒歩行動における エネルギー消費量も減少する。しかし、高齢者にとってエネルギー 消費量が減ることで徒歩行動による体力的負担が小さいことはいえ ない。加齢に伴い、生命維持のための基礎代謝量も低下寸ることで 移動のエネルギー消費量が少なくても、高齢者のエネルギー必要量 に対して割合が大きいことが考えられる。そこで本研究においては、 都市内移動によるエネルギー消費量の算出結果を利用し、厚生労働 省の食事摂取基準 2015 年度版 $\left.{ }^{15}\right)$ に示されている年齢別の一日エネ ルギー必要量に対する移動エネルギーの割合（\%)を算出し、これを 用いて都市内アクセシビリティを定量化する。この結果を図 3 に示 す。

図 3 により、移動時間結果と同様にエネルギー消費量からみても 移動距離によって各公共交通機関の得失の変化が激しいことが分か る。短距離移動範囲 $(1200 \mathrm{~m})$ の場合、バス停の密度が非常に高いこ とにより、バス停までの徒歩距離が短いため歩行のエネルギー消費 量が少ない。一方、バスより駅間の間隔が長い BRT または地下鉄の
場合は、駅までの徒歩距離の影響で全体移動のエネルギー消費量が 大きいことが分かる。特に、地下鉄の場合は、長距離範囲でもエネ ルギー消費量が非常に高く、他の交通機関に比較すると圧倒的に大 きいことがみてとれる。また、徒歩時間が長く、体力的負担が支配 的となり、高齢者にとって、より利便性が低下寸る結果となった。 さらに、気候条件なども影響を与えると考えられるので気温が高い 都市や低い都市などでは、より顕著となると予想される。

移動距離が長くなるほど BRT と地下鉄よりバスの乗車時間のほう が長いため、エネルギー消費量の増加は他の交通機関より大きいこ とが分かる。平均値の結果から、移動距離範囲 $4800 \mathrm{~m}$ の場合はバス 利用時のエネルギー消費量が BRT 利用時とほぼ同量であるが移動距 離範囲 9600m の場合、バス利用時のエネルギー消費量が BRT と地下 鉄利用時のエネルギー消費量を上回ることが示される。最大值の結 果からみると、最も利便性が低い地点は、どの移動距離の場合にお いても、各公共交通機関利用時の移動エネルギー消費量の差が平均 值の場合より大きいことが分かる。

年齢階級ごとの移動による一日エネルギー必要量に対する割合の 結果は、加齢に伴って大きくなり、移動行動による体力に及ぼす影 響は高齢者が最も大きいことが見てとれる。特に、移動距離範囲 $9600 \mathrm{~m}$ の場合は、高齢者の移動によるエネルギー必要量に対する割 合が非高齢者の割合の 1.5 倍であり、移動距離が長いほど年齢階級 ごとの差が上昇することが分かる。短移動距離の場合の徒歩距離お 
よび、長移動距離の場合の乗車時間、どちらも高齢者にとって都市 内移動による体力的負担に大きな影響を与えることが考えられる。

\section{5 適用結果および考察}

移動時間とエネルギー消費量から見た、移動距離の変化による各公 共交通機関の得失を図 4 に示寸。図 4 は後述の図 6 の左側の抵抗係 数のグラフとは異なり、移動に係るエネルギー消費量および移動時 間の総量を示すため、グラフの左端すなわち移動距離が 0 の場合に は、エネルギー消費量、移動時間は 0 となる。移動距離 $1200 \mathrm{~m}$ の地 点からは、完全に交通機関利用になるので、この地点を境に各交通 機関の移動時間、エネルギー消費量の増加率すなわちグラフの傾き が小さくなる。この結果より、バスは、短距離では徒歩時間が短い ため移動時間とエネルギー消費量の利便性が他の交通機関より高い が、移動距離が長いほど不利になる。これに対して地下鉄は、速達 性に優れるため移動時間の利便性が高いが、駅間隔が長いことによ り体力的負担が高いことも分かる。一方、BRT利用の場合には、移 動時間の利便性は地下鉄とほぼ同様であり、エネルギー消費量の利 便性も他の交通機関より非常に高いことが見てとれる。

また、各交通機関の利便性が逆転する移動距離（図 4 の○印）に ついては、エネルギー消費量より移動時間の方が逆転の起こる移動 距離が小さいことが分かる。年齢別の結果によると、高齢者の方が、 非高齢者よりエネルギー消費量の利便性逆転距離が小さいことが分 かる。しかし、移動時間については、逆に非高齢者の逆転距離が小 さいことが分かる。この理由は、徒歩距離と交通機関利用時間の影 響は非高齢者より高齢者の方が大きいためであると考えられる。こ のことから、公共交通機関導入時には、地域の人口構成が重要な判 断基準になると思われる。なお、本章で定式化されたモデルでは徒 歩移動による抵抗は距離に比例するとして計算した。しかし、実際 に長距離を徒歩で移動する場合には、疲労によって単位距離当たり の抵抗が増加し、以上の結果よりもさらに徒歩距離の影響が大きく なる懸念がある。これについては、次章の実証研究において考慮す ることにする。

近年、日本のみならず東アジア諸国では、高齢化問題が顕在化し てきており、都市構造の転換が必要になってくると考えられる。日 常生活の移動時間が短いことが必要不可欠であるが、移動制約者が 増加している新たな社会に適合性が高い交通機関の選択も非常に重 要な問題である。以上の分析結果より、地下鉄は、速達性に優れる

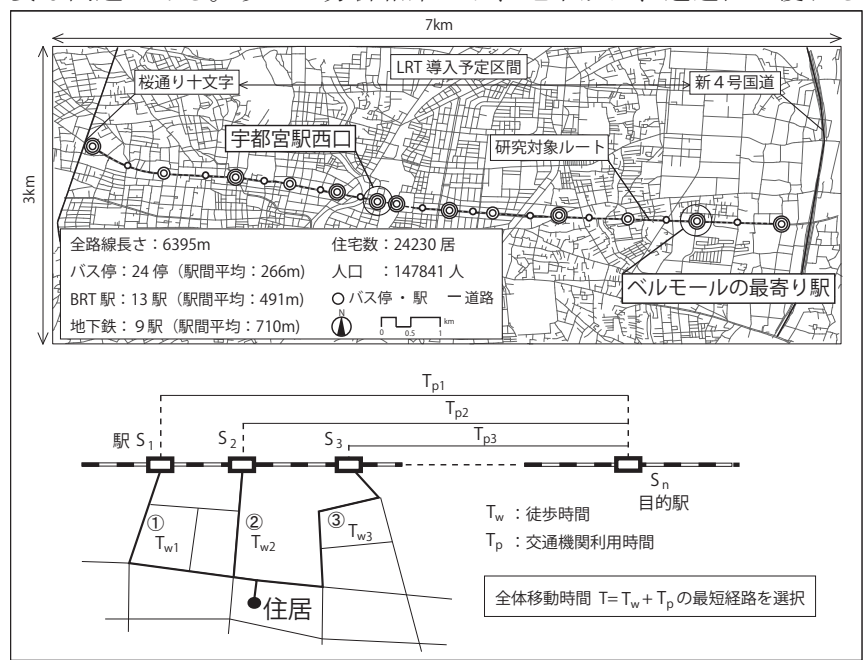

図 5 対象地域の概要
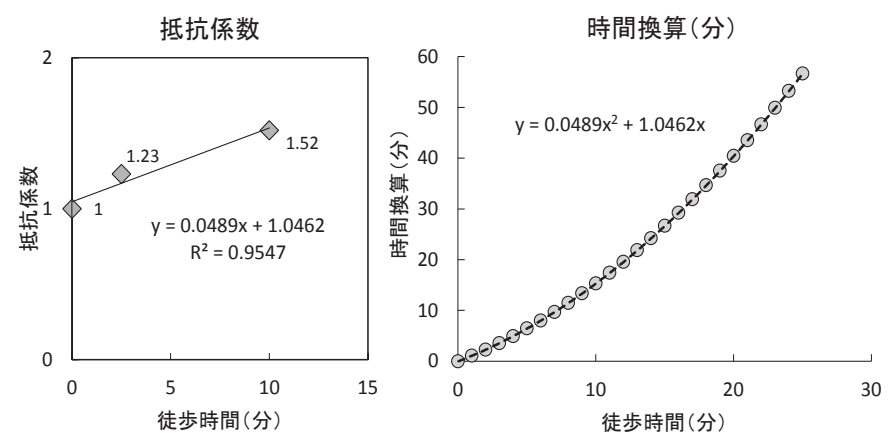

図 6 徒歩移動抵抗図

ことで大きな移動時間短縮効果が生まれるが、駅から離れる領域に 暮らす住民にとって徒歩時間が延び、それによって移動による社会 的負担が高齢化によって大幅に増加寸ることが考えられる。一方、 既往のバスより性能や運行方針が改善される BRT は、都市内の日常 生活に伴う移動距離に対して駅間も短く速度が速いことにより、快 適かつ利便性が高い交通機関となり得る。以上のことと、比較的低 コストであること、高い柔軟性を持つことから、BRT は注目される 公共交通機関となっていると考えられる。

3. 宇都宮駅周辺を対象とした都市内アクセシビリティの定量的評価 本章では、前章で定式化した評価手法を用いて、宇都宮駅周辺を 対象とし、移動コストを定量化して都市内アクセシビリティを評価 する。

\section{1 対象地域の概要}

対象地域は、宇都宮駅の中心地とする図 5 に示寸地域とする。平 成 25 年 3 月に、宇都宮市が策定した「東西基幹公共交通の実現に向 けた基本方針」においては、JR 宇都宮駅西側の中心市街地と、鬼怒 川左岸の工業団地や大規模開発地区を結ぶ「桜通り十文字付近〜東 武宇都宮駅〜 JR 宇都宮駅〜宇都宮テクノポリスセンター地区 (約 $15 \mathrm{~km} 、 19$ 停留ヶ所)」が計画区間となっている ${ }^{21)}$ 。本研究では、こ の計画区間の一部（桜通り十文字付近〜新 4 号国道、約 $6.4 \mathrm{~km}$ ）を対 象路線とし、路線を挟んで南北それぞれ $1.5 \mathrm{~km}$ 、幅 $7 \mathrm{~km}$ にわたる地 域を対象地域とした。各住宅を出発地点とし、目的地は宇都宮駅西 口と対象地域内で大型のショッピングセンター (ベルモール) の最 寄り交通機関停留場とした。これは、対象地域の中心地と端部の 2 つの目的地を設け、移動コストの比較を行うためである。

\section{2 移動コスト推定方法の概要}

対象路線上に、バス・BRT・地下鉄の各公共交通機関を設定した。 交通機関のそれぞれ移動速度は前章の解析（表 1) と同様、バス停・ 駅位置は実際のバス停位置およびLRT の基本方針で策定された停留 場位置を参照して決めた。バス停・駅の数と駅間の間隔を図 5 に示す。 徒歩速度については、非高龃者（15-29歳）のみを対象とした。

本研究の使用データは、総務省統計局による $\mathrm{H} 22$ 国勢調查の小地 域集計、ゼンリン建物ポイントデータ 2013 版（建物点）、H21 国土 数值情報 (100mメッシュ土地利用)、ArcGIS Data Collection「道 路網 2014」とした。これらを用いてArcGIS の Network Analyst 一ルで全ての建物点から目的地までの道路距離を計測し、総移動時 間（徒歩時間十交通機関利用時間）が最短となる経路での移動時間 を算出した。また、地下鉄による移動では、駅のホームが地下 2 階 
にあると想定し、地上とホームの間の移動時間は階段上り下りで 2 分を考慮した。一方、BRTによる移動の場合は、道路中央にバスレ ーンが設けられると想定し、道路を横断するための信号の待ち時間 を 30 秒とした。

本章の対象地域は、第 2 章で想定した対象地域の幅である $1.2 \mathrm{~km}$ よりも大きい $1.5 \mathrm{~km}$ の幅を想定している。これは、当該地域の特性 を踏まえ、また地方都市ではパーソントリップ調査の結果などから 遠距離の徒歩移動も少なからず存在することを反映させたものであ る。前章の解析中、徒歩行動によるエネルギー消費量算出式では、 体力的負担は徒歩時間に比例するものと想定した。しかし実際には、

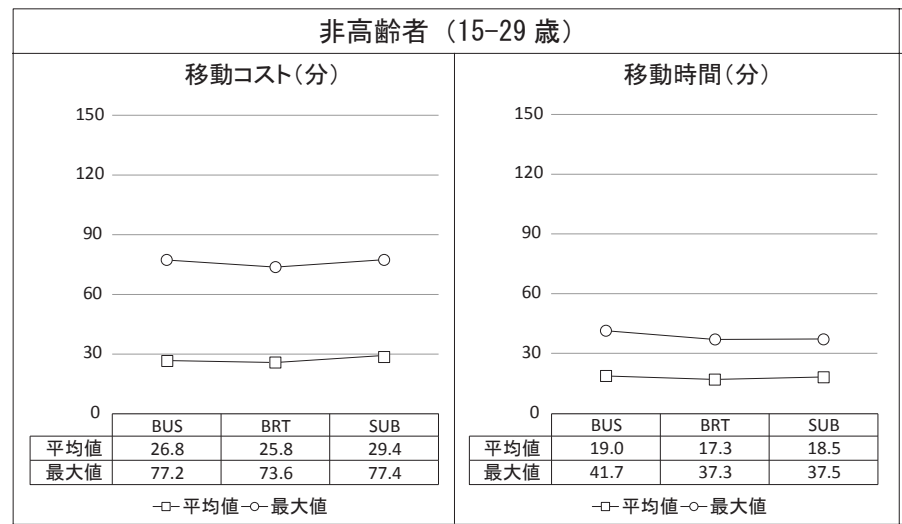
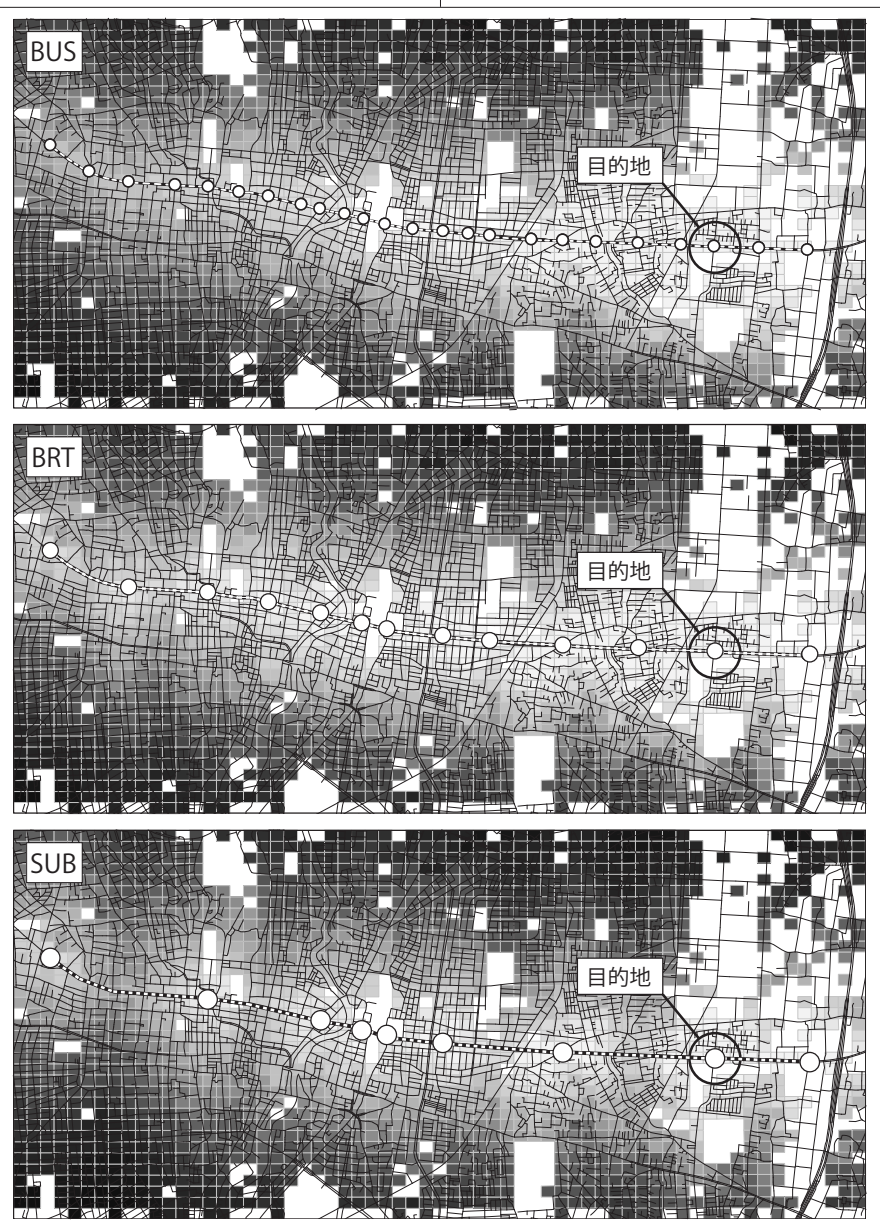

移動コスト(分)

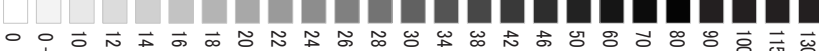

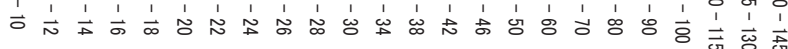

徒歩時間が長くなると身体の抵抗が増加することが考えられる。従 って、本章では、徒歩抵抗係数を定数ではなく、徒歩時間の増加に 伴って増加する、すなわち身体の抵抗は徒歩時間と非線形関係であ る方が適切であると考えられる。既往研究においてこのような徒歩 抵抗係数を徒歩時間の増加に従って増加させたモデルを詳しく探求 したものは見当たらない。松橋 22) が紹介するドイツの近距離交通基 盤整備の投資基準が 2006 年版 ${ }^{23)}$ においても類似の考え方を用いて いるが、算定根拠が示されておらず、かつ 40 秒以内では徒歩抵抗係 数が 1 を下回る、すなわち徒歩の方がより望ましいことになり、1 分以内ではグラフが示されていない。そこで本章では、既往研究の

\begin{tabular}{|c|c|c|c|c|c|c|c|}
\hline \multicolumn{8}{|c|}{ 高齢者（70 歳以上） } \\
\hline & \multicolumn{3}{|c|}{ 移動コスト(分) } & \multicolumn{4}{|c|}{ 移動時間 (分) } \\
\hline 150 & \multicolumn{3}{|c|}{0} & & & & \\
\hline 120 & & & & 120 & & & \\
\hline \multicolumn{4}{|c|}{90} & 90 & & & \\
\hline 60 & & & & \multirow{2}{*}{$\begin{array}{l}60 \\
30\end{array}$} & \multicolumn{3}{|c|}{0} \\
\hline & $\square$ & $\square-$ & $\square$ & & $\square$ & $-\square$ & \\
\hline 0 & BUS & BRT & SUB & 0 & BUS & BRT & SUB \\
\hline 平均値 & 42.6 & 42.8 & 48.5 & 平均値 & 24.8 & 23.3 & 25.1 \\
\hline 最大値 & 137.8 & 134.8 & 144.0 & 最大値 & 56.1 & 51.8 & 52.4 \\
\hline
\end{tabular}
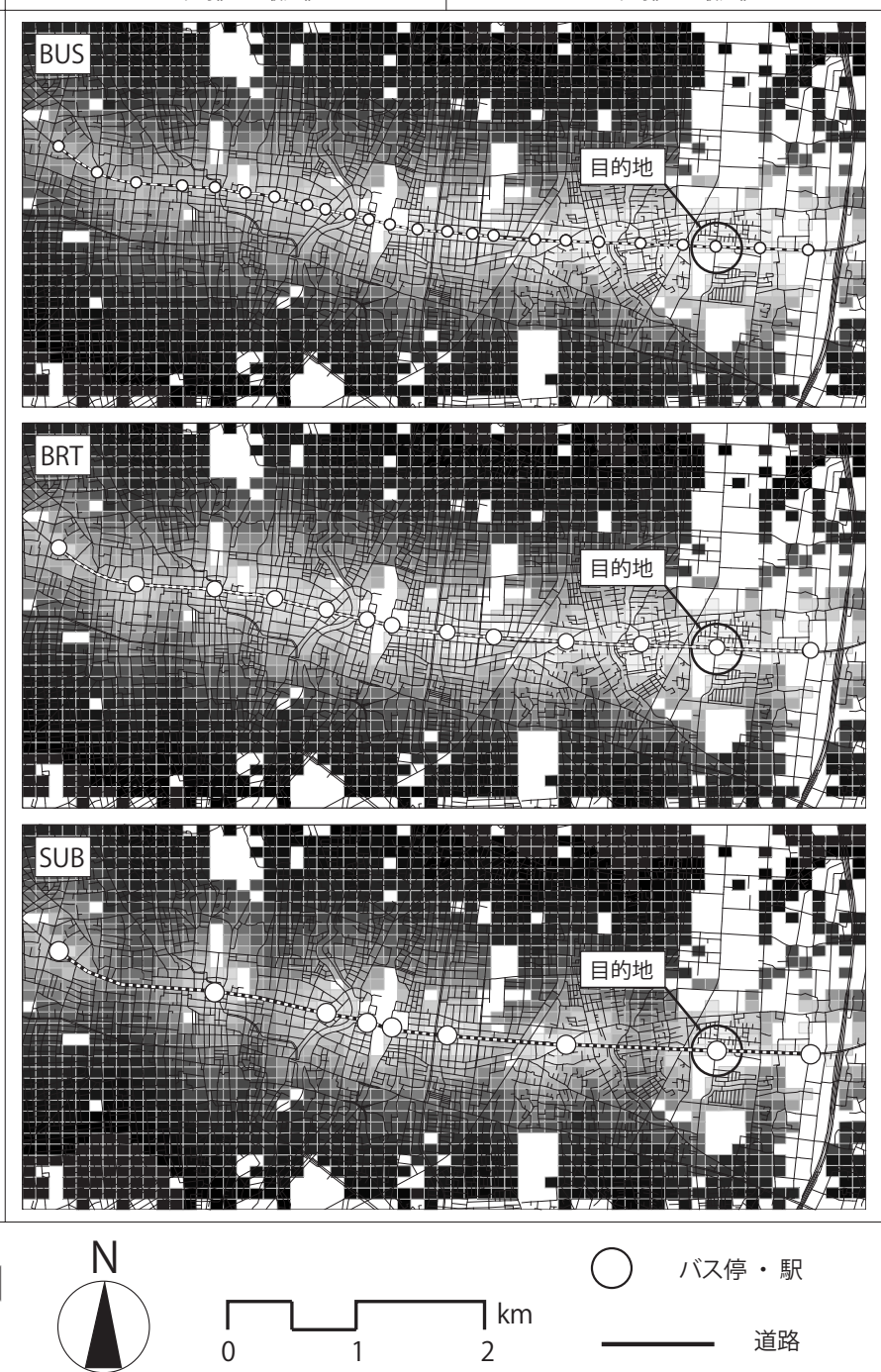

○バ停・駅 道路

図 7 ショッピングセンターの目的地として各公共交通機関利用時の移動コスト 
徒歩抵抗係数と徒歩距離との関係をもとに、徒歩抵抗係数を定式化 する。

短距離徒歩の場合は、塚田ら ${ }^{24)}$ によれば駅内の乗り換え行動を対 象として立位時間を基準とした場合には水平移動の等価時間係数は 1. 32、加藤ら ${ }^{25)}$ によれば乗車時間の基準に対して水平歩行時間バラ メータの推定值は 1.23 となっている。これらの推定值はほぼ等しい が、加藤ら ${ }^{25)}$ の条件が本章の設定条件（徒歩時間と乗車時間の条件） に近いことから、1.23 を利用することにした。また、既往研究で分 析対象となった各駅のレイアウトを検討したところ、乗り換え行動 による徒歩距離が概ね $200 \mathrm{~m}$ であった。この距離を徒歩の一般速度

\begin{tabular}{|c|c|c|c|c|c|}
\hline \multicolumn{5}{|c|}{ 非高齢者 (15-29 歳) } \\
\hline \multicolumn{2}{c|}{ 移動コスト(分) } \\
\hline
\end{tabular}
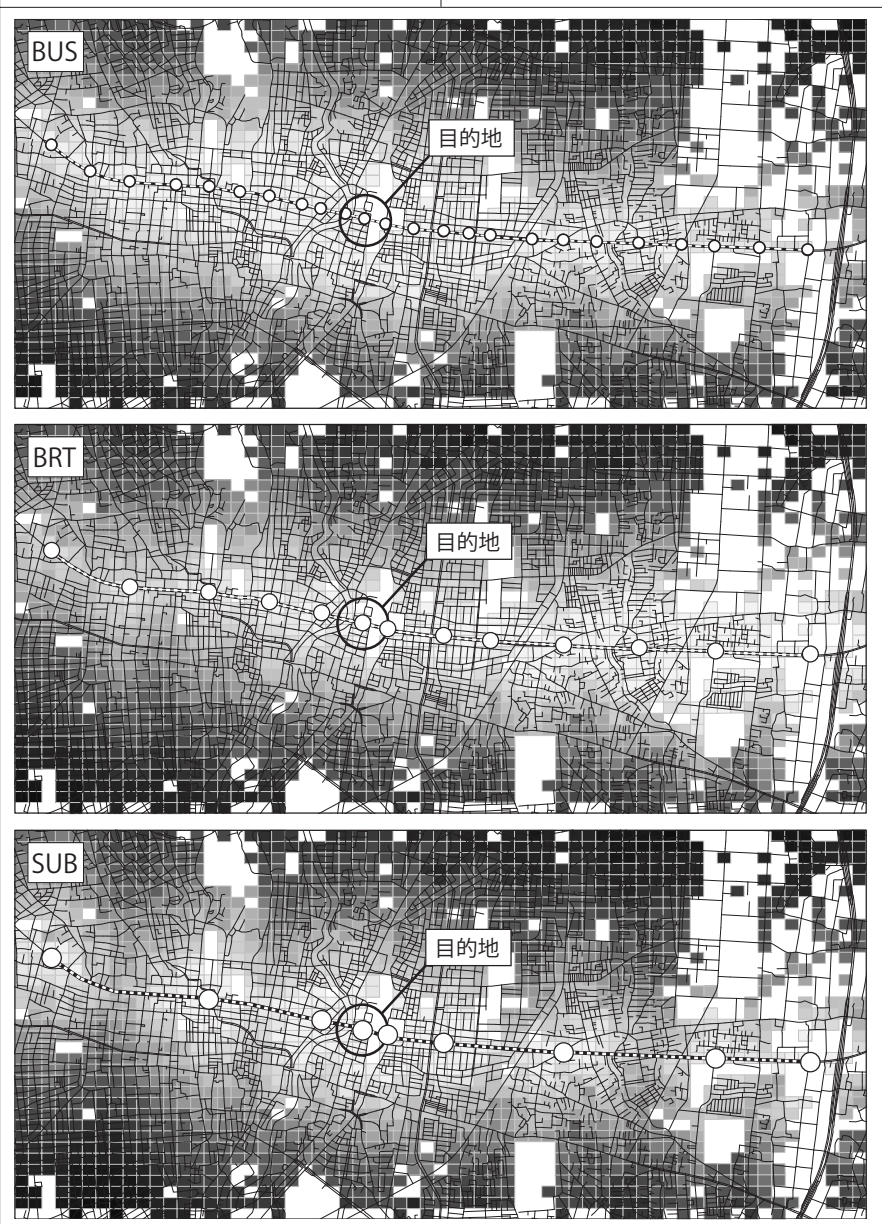

移動コスト (分)

低------------- 高

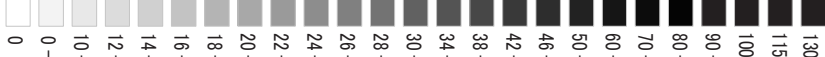

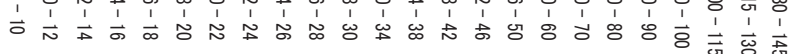

(80m/ 分) で割り、徒歩時間 2.5 分に対する徒歩抵抗係数を 1.23 と する。

一方、長距離徒歩については、大佛・津田 ${ }^{8)}$ が施設の利用者行動 を推定するために、移動コストを定式化している。移動コストバラ メータの推定数值を移動手段別の速度で割ると、鉄道移動時間の基 準に対して水平徒歩コストバラメータの推定数は 1.52 となった。徒 歩距離については既報 26, 27) が、「300〜 400m 以上になると歩く意欲 が減少し、600〜800m を越えるとバス等の代替手段が不可欠になる こと」と示唆している。また、大佛らの分析での対象となった横浜 市地域で GIS ネットワークを用いて住宅から最寄りバス停または駅
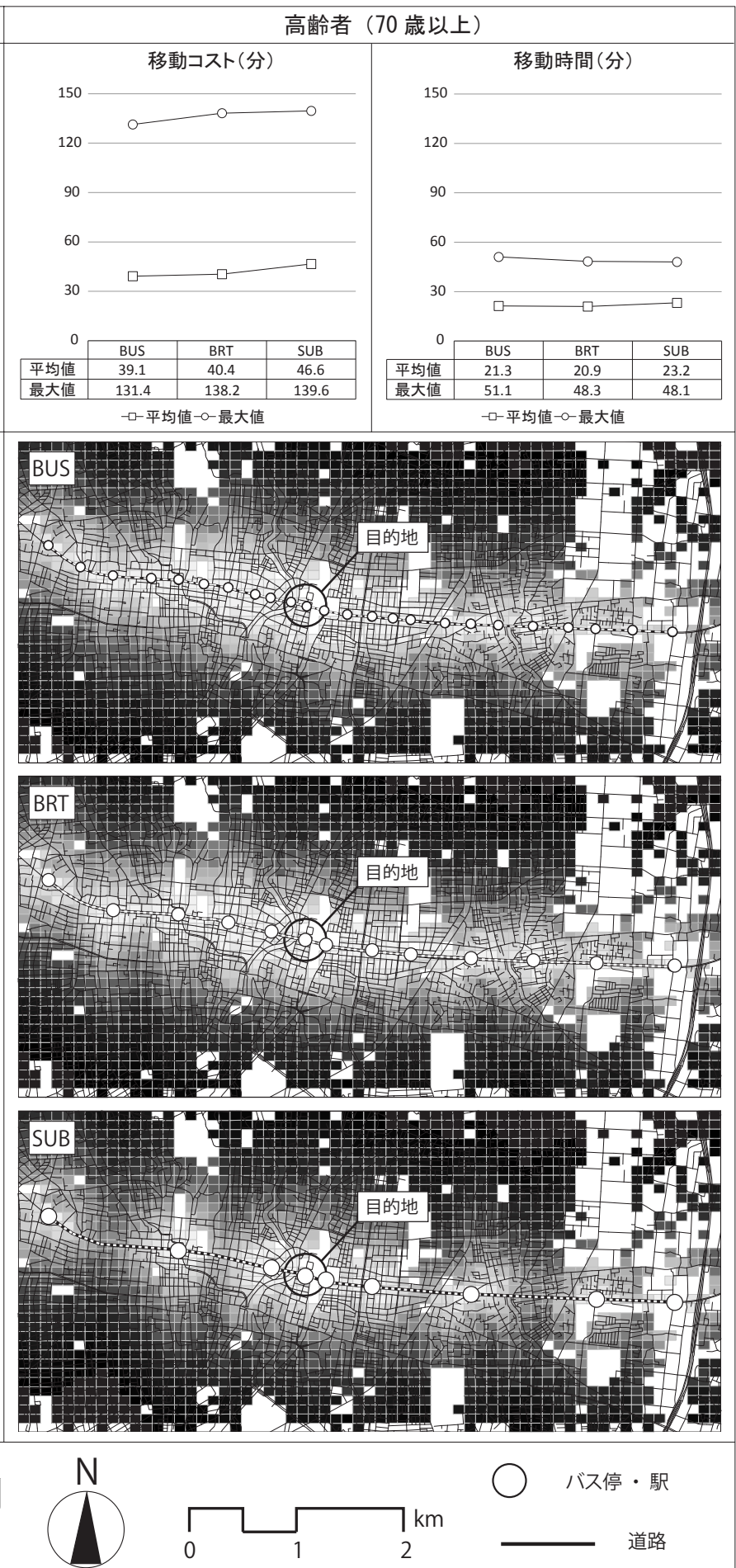

図 8 宇都宮駅西口の目的地として各公共交通機関利用時の移動コスト 
までの道路距離を測ったところ、平均徒歩距離が約 $800 \mathrm{~m}$ 、すなわち 徒歩時間が 10 分になった。そこで、徒歩時間 10 分に対する徒歩抵 抗係数を 1.52 とした。

さらに、移動時間が 0 の場合には、徒歩時間と他の時間はほぼ等 価と考えられるので、徒歩抵抗係数は 1 に近い值となることが望ま しい。

以上の 3 点の徒歩抵抗係数および徒歩時間のデータを用いて、関 数として最も単純な線形関数を想定し、図 6 左のように徒歩時間に よる徒歩抵抗係数の関数を回帰分析により決定した。原点すなわち 徒歩時間が 0 の場合には、抵抗係数は 1 をわずかに超えた值となっ ている。これをもとに実際の徒歩時間と時間換算の結果を示したの が図 6 右である。この縦軸は図 4 の移動時間の縦軸と同じ意味を持 っている。したがって、図 4 の左端すなわち移動距離が 0 の場合は、 図 6 右の左端すなわち移動時間が 0 の場合に対応し、縦軸の時間換 算も 0 となって、図 4 と整合している。この結果により、乗車時間 を基準とした場合、各建物点からの徒歩時間を移動コストに換算す ることができる。

上記の前提に基づき、全ての建物点から目的地まで求めた移動コ ストを、建物点に付与されている情報である「個人の家屋総面積」 によって国勢調查小地域集計の人口を接分し、この按分人口によっ て移動コストをメッシュ毎で加重平均することで、平均移動コスト を求めた。

\section{3 移動コストの推定結果}

対象地域の端部に位置しているショッピングセンターの目的地と して年齢別の各公共交通機関利用時の移動コスト分布を図 7 に示寸。 全体的に路線沿いおよび目的地周辺の移動コストが小さく、路線か ら離れた南北部の地域は徒歩距離が長いため中心部の移動コストの 約 3 倍である。各交通機関と比較すると、BRT と地下鉄がバス利用 より全体的に移動コストが小さいことが分かるが、駅間隔の影響に より建物点の位置によって移動コストが急速で増加することも再現 できた。特に、地下鉄利用の場合は、駅周辺の移動コストが同心円 状になる一方、駅と駅の中点から移動コストの高い地域が急に広が ってくることが分かる。BRT については、他の交通機関より移動コ ストの低い地域が広く、路線から離れた場合の移動コストの増加が 緩やかである。さらに、移動コストの集計結果により、どの年齢に とっても地下鉄の移動コストは最も高く、BRTの移動コストは最も 小さいことが分かる。また、この結果から、移動時間については最 大值が平均值の 2 倍以上になり、さらに移動コストの最大值は平均 值の約 3 倍であり、差が非常に大きいことがわかる。この理由とし ては、最も利便性が低い建物点が交通機関路線から離孔、徒歩距離 が長いためと考えられる。各交通機関別の移動時間をみると、前章 の解析結果と同様に、速達性に優れることから、バスより BRT と地 下鉄の移動時間のほうが短いことが再現できた。年齢別の結果と比 較すると、高齢者は交通機関利用時に非高齢者より圧倒的に移動コ ストが高く、移動時間が長いことが分かった。高齢者は若者より徒 歩速度が遅いことで徒歩時間が非常に長くなる。これによって、高 齢者にとって移動行動による精神と体力的負担が他の年齢より大き く、移動コストが非高齢者の結果の 2 倍程度になった。特に、地下 鉄利用時は他の公共交通機関より徒歩時間が支配的となり、高齢者 にとって利便性が低くなる。
続いて、建物点から対象地域の中心に位置している宇都宮駅西口 の移動コスト分布を図 8 に示す。対象地域の中心に立地しているた め、移動コストが小さい。しかし、目的地が中心にあることで交通 機関の利用時間が減少する、直接に徒歩で向かうことができる建物 点以外では、建物点からバス停・駅までの徒歩時間はほぼ変化しな い。これによって、建物点の位置によって移動コストの差が大きい ことが分かった。特に、地下鉄は、他の交通機関より利便性が低い 地域が多い、図8において、移動コストの最大值が大きいことから 確認できる。またバス利用の場合は、移動距離が短いことによりメ リットが生じ、BRT と移動コストがほぼ一致し、地下鉄よりやや低い。 移動時間については、各交通機関の得失は最大值と平均值では逆転 しているが、どの場合にも BRT が均衡が取れた結果を与えることが 分かった。年齢別と比較すると、目的地を変えても高齢者は徒歩移 動よる体力的負担が大きいことで非高齢者より移動コストが圧倒的 に高いことが分かった。

\section{4 交通機関，対象施設別比較と考察}

図 7 と図 8 の結果を比較すると交通機関と対象施設位置が移動コ ストに大きな影響を及ぼすことが分かる。施設が地域の中心部にあ る場合（図 8)、移動距離が短いため、住宅から乗り場が近く、すぐ に乗車できるバスまたは BRT は移動コストが小さくメリットがある。 地下鉄は乗車時間が短いが駅までの徒歩時間が長く、体力的負担が 大きいことで移動コストが他の交通機関より高くメリットが小さい。 一方、移動距離が長く中心部から離れた施設の場合（図 7) は、速達 性の高い地下鉄と BRT はバスより移動時間が短く大きなメリットが ある。しかし、駅までの徒歩距離が長いことに加えて駅内でもホー ムまでの移動時間と階段上り下りによる体力的な移動抵抗があるこ とで、地下鉄の移動コストが相対的に高いことが示された。以上の 結果から、移動距離によって各交通機関のメリットの変化が生じる ことが分かった。

\section{4 おわりに}

本研究では、公共交通機関整備による住環境の利便性向上を評価 するために、都市内移動をモデル化することにより、都市内アクセ シビリティを定量的に評価する手法を定式化した。仮想都市におけ る解析結果より、地方都市での都市内の移動時間、特に徒歩時間には、 駅間距離が大きな影響を及ぼすことがある。さらに、この影響が年 齢階級ごとに、徒歩速度と人間のエネルギー代謝率、基礎代謝率に より、異なることが分かった。また高齢化が進む地方都市での都市 内の移動時間短縮には、各交通機関の速達性や駅密度を増加させる よりも、各地点から駅までの移動時間を短縮した方が効果が大きい ことが示唆された。さらに、定式化した手法に基づいて、宇都宮市 の中心地域を対象とし、建物点から各交通機関利用時に対象施設別 の移動コスト推定の検討を行った。本分析でも仮想都市における解 析結果と同様に、移動距離により交通機関のメリットが变化するこ とが再現された。またバス、BRT、地下鉄それぞれの利便性に、移動 抵抗の移動距離、徒歩移動と地域の人口分布が及ぼす影響を確認し、 新交通システム導入の際に都市の規模・形態と需要密度に適合性が 高い交通機関の選択は重要であることを示した。

この結果より今後の課題として、以下が挙げられる。都市内水平 移動の障害 (幹線道路、ゲーティッドコミュニティ、大規模建築物 )、 
垂直移動の障害（超高層建築物のエレベータ利用時間）をモデルに 組み込んだ場合の影響、さらに実際の都市にとっての新型交通シス テムの導入の効果や提供の可能性に関する研究を進める必要がある。 現在進行している超高層建築物の建設や、横断困難な幹線道路建設、 進行待ち時間の増加等による徒歩移動負荷の拡大によって、公共交 通機関の導入による負荷低減効果が減少する懸念がある。高齢化や 地球温暖化を考慮した場合、現在進行している都市開発プロジェク トが実際に都市内アクセシビリティの向上に向かっているのか、従 来に比較して都市内アクセシビリティの分布にどのような偏りが生 じるのかを検討することが必要になると考えられ、このために本研 究で定式化した評価手法が有効であると期待できる。また、本研究 で対象とした移動抵抗としての移動距離、徒歩時間、体力的負担以 外の、待ち時間や運賃などの抵抗も検討し、都市内アクセシビリテ イの定量的評価を精度良く推定することも今後の課題である。なお、 本論文は、著者らによるパイロットスタディー ${ }^{28)}$ の結果を発展させ たものである。

\section{謝辞}

本研究は、首都大学東京「アジア人材育成基金」の一環として行わ れた。

\section{注}

注 1）他の公共交通機関としてモノレール、新交通システム、ガイドウェイバ ス（名古屋市、ゆとりーとライン、2001 年、など）、LRT などが考えられる。 このうち、モノレールや新交通システム、ガイドウェイバスは、駅が立体 になっていて軌道が自動車交通と完全に分離されていて性能としては地下 鉄に近いため、本研究では地下鉄に類似するものと考えた。一方で LRT は, 性能としてはBRT に近く、BRT に比較して建設費が非常に高価である。この ため、我が国では LRT の最近の設置事例は少ない（富山県富山市など）。こ れに対してBRT は、定義にもよるが、著名な事例である名古屋市基幹バス （1982 年）以降にも、東日本大震災による鉄道不通区間の代替のみならず、 最近の設置事例が増加している。たとえば、茨城県石岡市・小美玉市（か してつバス専用道、2010 年)、茨城県日立市（ひたち BRT、2013 年）、新潟 県新潟市（萬代橋ライン、2015 年）が挙げられる。さらに BRT は開発途上 国など海外での事例も多い。そこで本研究では、LRT とBRT を代表して BRT を取り上げることとした。

\section{参考文献}

1) 神足祐太郎：バス高速輸送システム (BRT), 導入事例と論点、国立国会図書 館調査及び立法考査局、レファレンス 63 (6)、pp. 43-56、2013.06

2) 佐藤栄治・吉川徹・山田あすか：地形による負荷と年齢による身体能力の 変化を勘案した歩行換算距離の検討，地形条件と高齢化を勘案した地域施 設配置モデル その 1、日本建築学会計画系論文集、第 610 号、pp. 133-139、 2006. 12

3）山塙哲史・吉田聡・佐土原聡 : 生活関連施設へのアクセシビリティ評価に よる地域特性分析、日本建築学会大会学術講演梗概集、F-1、pp. 787-788, 2007. 8

4）繁野北斗・吉川徹・讃岐亮 : 水平方向の徒歩移動抵抗に立脚した中心市街 地の施設立地分析，施設訪問行動の目的性に着目して、日本建築学会大会 学術講演梗概集、F-1、pp. 1013-1014、2012.9
5）池田亘・出口敦 : 高齢化進行地区における徒歩からみた市街地評価に関す る研究、日本建築学会大会学術講演梗概集、F-1、pp. 255-256、2010.7

6）杉山允宏・桐島日出夫・平谷昭彦・大八木達也：歩行のエネルギー消費、 人間工学、第 17 巻、第 6 号、pp. 259-265、1981

7) 煤孫光俊 - 大瀧保明 - 鈴木明宏 - 佐川貢一・石原正 ・猪岡光 : 移動形態と 歩行速度を考慮した消費カロリーの無拘束推定、計測自動制御学会東北支 部 第 202 回研究集会、資料番号 202-11、2002

8）大佛俊泰・津田さやか：都市内移動の手段と方向性を考慮した移動コスト の施設利用選択行動モデルへの組み込み、日本建築学会計画系論文集、第 77 巻、第 676 号、pp. 1293-1300、2012. 6

9）佐藤寛之・青山吉隆・中川大・松中亮治・白柳博章 : 都市公共交通ターミ ナルにおける乗換抵抗の要因分析と低減施策による便益計測に関寸る研究、 土木計画学研究・論文集、第 19 巻、第 4 号、pp. 803-812、2002.9

10）杤木県：新交通システム、新交通システム導入の検討状況（宇都宮地域）、 http://www. pref. tochigi. 1g. jp/h03/town/koukyoukoutsuu/shinkoutsuu/ 1rt_index.htm1、参照 2014.7.14

11）平林英樹：GPS データを用いた駅端末バスの速度低下要因の分析、芝浦工 業大学工学部土木工学科卒業論文梗概、2006

12）神奈川県：鉄道と LRT の基本特性の比較 : http://www. pref. kanagawa.jp/ cnt/f6601/p19849. html、参照 2014.7.7

13）阿久津邦男：歩行の科学：運動不足克服のために、不昧堂新書、p. 56、 1975

14）佐藤栄治：居住者や利用者に着目したアクセシビリティに関する立体的 都市空間の分析指標の開発と都市空間再構築手法の提案、博士論文、p. 68 、 2006. 9

15）厚生労働省：日本人の食事摂取基準（2015 年版），策定検討会報告書、 2006. 3

16）佐藤方彦：人間工学基準数值数式便覧、技報堂、p. 204、1992

17）厚生労働省：健康づくりのための運動指針（2006）、p.6、2006

18）松林静輝・中村嘉隆・白石陽・高橋修：METs エネルギー換算法に基づく 生活活動時の消費カロリー計測手法、マルチメディア・分散・協調とモバ イル (DICOM02012) シンポジウム論文集、pp. 2161-2169、2012.7

19）健康用語Weblio 辞書: http://www. weblio. jp/content/METs、参照 2014.7.7

20）厚生労働省：生活習慣病予防のための健康情報サイト：http://www. e-healthnet. mhlw. go. jp/information/exercise/s-02-004.html、 参 照 2014. 7. 14

21）宇都宮市：新交通システム、東西基幹公共交通（LRT）の実現に向けた取り 組み: http://www. city. utsunomiya. tochigi. jp/kotsu/shinkotsu/026687. html、参照 2014.7.7

22）松橋啓介：公共交通機関の停留所の立地が徒歩アクセスと替在的利用人口 に与える影響、日本都市計画学会学術研究論文集、第 37 回、pp. 157-162、 2002. 10

23) Intraplan Consult GmbH : Standardisierte Bewertung von Verkehrswegeinvestitionen des öffentlichen Personennahverkehrs、 p. 27、2006

24）塚田幸広、河野辰男、田中良寛、諸田恵：一般化時間による交通結節点 の利便性評価手法、国土技術政策総合研究所資料、国総研資料第 297 号、 pp. $35-49 、 2006.2$

25）加藤浩徳・芝海潤・林淳 - 石田東生 : 都市鉄道駅における乗継利便性向 上施策の評価手法に関する研究、季刊「運輸政策研究」、Vol. 3、No. 22000 Summer（通巻 009 号)、pp. 9-20

26) 宮崎正訳：楽しく歩ける街、OECD 編、PARCO 出版局、p. 21、1975 27）紙野桂人：人のうごきと街のデザイン、彰国社、p. 132、1980

28) LE PHONG NGUYEN・吉川徹 : 公共交通機関による都市内移動時間に関する基 礎的研究、日本建築学会大会学術講演梗概集、F-1、pp. 995-996、2015.9 


\section{A METHOD FOR QUANTITATIVE EVALUATION OF URBAN PEDESTRIANS ACCESSIBILITY BY PUBLIC TRANSPORT}

\section{LE Phong Nguyen * and Tohru YOSHIKAWA**}

\footnotetext{
* Doctoral Course in Architecture and Building Engineering, Tokyo Metropolitan University, M.Eng. ** Prof., Dept. of Architecture and Building Engineering, Tokyo Metropolitan University, Dr.Eng.
}

In recent decades, many cities in the world has started to apply policies and development projects that aim to increase their citizens' convenience of life, which is considered one of the most basic criteria to a high quality living environment. The most obvious example is building subway, monorail, LRT (Light Rail Transit) as well as BRT (Bus Rapid Transit) systems to reduce inner city travel time, thus, enhance public transport convenience and quality of life. Especially, for an aging population country like Japan, the switch from using private transport to public transport is necessary in order to adapt to the current rapid change of its population's density and social structure.

Actual urban public transport planning needs to select transport means that not only have appropriate speed and level of punctuality but also are compatible with the scale, structure and the demand of each city's population. Among the above requirements, everyday travel time is one of the most significant criteria to evaluate quality of life. Apart from travel speed and density of public transport terminals, walking time between home and stations crucially affects total travel time within urban areas. Because each person's commuting ability depends on age and physical ability, the sphere of walking should be carefully considered in public traffic transport network planning in order to enhance the living convenience.

This research focuses on walkability and accessibility, aims to evaluate travel quality of each public transport in urban areas by using algorithmic models to analyze travelling time as well as physical and mental consumption index of public transport users. In addition, the study also conducts quantitative analysis on travelling quality in order to evaluate accessibility and applies the developed model to the central area of Utsunomiya City in order to verify the model.

The algorithmic model analyzes three basic public transport means in the city, which are bus, BRT and subway systems. The model assumes that the researched urban area is $1200 \times 1200 \mathrm{~m}$ wide, public transport routes are arranged horizontally in the center of the area, and the walking routes are arranged horizontally and perpendicularly, which means the walking distances are measured by the Manhattan distance metric. The model will calculate total traveling time of pedestrians including walking time and public transports using time. The sphere of travelling is assumed to be among the three distances that are $1200 \mathrm{~m}, 4800 \mathrm{~m}$, and $9600 \mathrm{~m}$. Using the total travelling time projected by the model, the study calculates total users' travel energy consumption by age. In addition, based on the algorithmic analysis of the central area of Utsunomiya City including JR Utsunomiya station as the centroid, the study analyzes the impact of walkability on people's travelling quality and research further on evaluating how convenient living environment in Utsunomiya city can be by the implementation of the three basic public transportation means.

Based on the final result, the study elucidates the impact of station distribution in term of density and distance on users' travelling time. Especially, the study analyzes different levels of travelling quality by public transports between ages based on factors of walking speed, weight and resting metabolic rate. The study gives specific results in convenience level of each public transport means which can be used as a basis for establishing the assessments and selection of most suitable transports in urban planning. 